\title{
TAXPAYER COMPLIANCE AT KPP PRATAMA SURABAYA MULYOREJO WITH RISK PREFERENCE AS A MODERATED VARIABLES
}

\author{
${ }^{1}$ Alif Faruqi Febri Yanto, ${ }^{2}$ Soeparlan Pranoto, ${ }^{3}$ Dwi Suhartini \\ 1,2,3 Universitas Pembangunan Nasional "Veteran" Jawa Timur \\ Email: aliffaruqi658@gmail.com
}

\begin{abstract}
This study aims to examine taxpayer compliance that is influenced by tax audits, knowledge of taxation and tax administration services moderated by risk preferences. The object in this study is an individual taxpayer registered at KPP Pratama Surabaya Mulyorejo. The analytical method used in this study is GSCA. The results showed that tax audits, fiscal services have an effect on taxpayer compliance, while tax knowledge does not contribute to taxpayer compliance. Risk preference moderates the relationship between tax audit and taxpayer services on taxpayer compliance, but cannot moderate taxation knowledge on taxpayer compliance.
\end{abstract}

Keywords: Tax Audit; Tax Knowledge; Fiscal Service; Risk Preferences; Taxpayer Compliance

\section{INTRODUCTION}

The definition of tax is based on Law no. 28 of 2007 regarding the third amendment of Law no. 6 of 1983 regarding General Provisions and Tax Procedures are: "Compulsory contributions to the State owed by personal or organizational forces which are compelling based on the provisions of the Law, without obtaining direct compensation and used in the interests of the State for the greatest welfare of the community". The government, which is the tax recipient, continues to strive to increase the amount of tax received to meet the APBN. Currently, taxes are a very potential source of revenue in the APBN framework. Based on a statement from the Ministry of Finance of the Republic of Indonesia, (Sri Mulyani Indrawati: 2016) revealed that currently Indonesia is ranked the 16th largest economy in the world, but Indonesia's tax ratio is still the same as various countries on the African continent. Indonesia's economic growth has not been 
EAJ (Economics and Accounting Journal) - Vol. 4, No. 1, Jan 2021 - Yanto, et al.

followed by an increase in tax rates for domestic or foreign tax subjects. Currently, Indonesia's tax ratio is around 10-290\% (Deni: 2016), even though the standard size of the ideal tax ratio that should be owned by Indonesia, according to the Director General of Taxes, is $15 \%$ and above. However, this must be done in stages from the percentage of the last tax ratio in 2019 of $10.7 \%$ so as not to cause economic shocks, therefore tax revenue is still small when compared to Gross Domestic Product shows that the level of taxpayer compliance is still low, thus there are possible taxes that the government can exploit from the people.

The following is presented in table 1.1 regarding taxpayer compliance issues in Indonesia from 2015 to 2019.

\section{Bar Chart 1. Taxpayer Compliance Problems in Indonesia in 2015-2019}

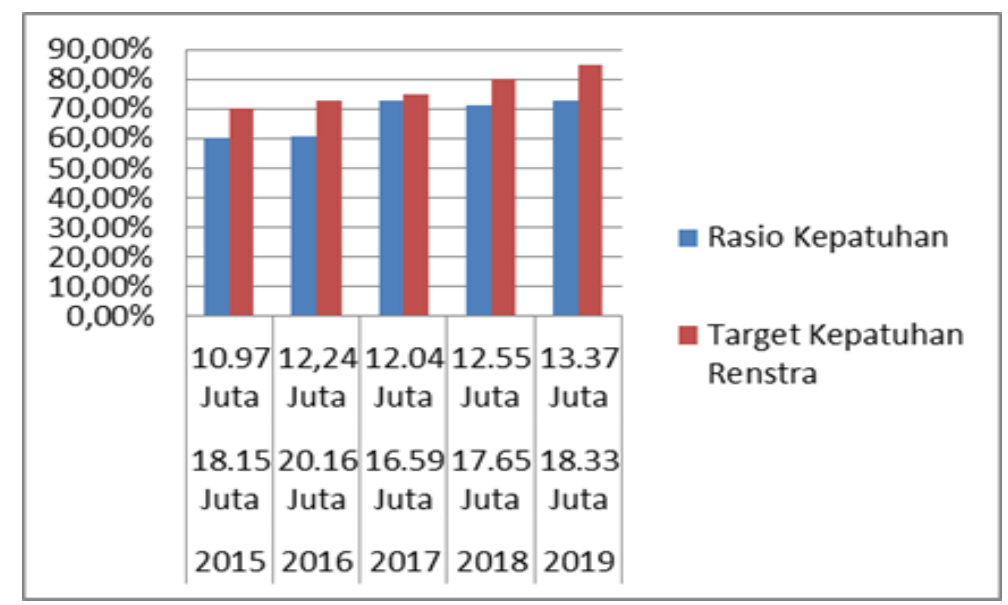

Source: pajak.go.id

Based on the problem of taxpayer compliance in Indonesia which is in table 1.1 it can be seen that there is a fluctuation every year. Over the last 5 (five) years the compliance ratio has not yet reached the predetermined target based on the targets recorded in the Ministry of Finance's Strategic Plan for 20152019 which shows that in that year there was a successive increase in the target of $70 \%$ in 2015 to $85 \%$ in 2019. There are several things that researchers can conclude from this problem. First, the level of compliance of tax subjects from both institutions and individual taxpayers is still very low, this is evidenced by very few Indonesians who have worked but did not register as taxpayers. Second, the level of compliance of taxpayers in Indonesia regarding tax payments is still very low. Third, disclosing if the level of compliance of Indonesian taxpayers regarding SPT reporting is still very low, this can be seen from during the last 5 (five) years the compliance 
EAJ (Economics and Accounting Journal) - Vol. 4, No. 1, Jan 2021 - Yanto, et al.

ratio has continued to fluctuate even though the target set by the government has never been achieved.

The following is presented in table 1.2 regarding the level of compliance of individual taxpayers at KPP Pratama Surabaya Mulyorejo from 2015 to 2020 .

\section{Bar Chart 2. Taxpayer Compliance Problems in KPP Pratama Surabaya Mulyorejo in 2015-2020}

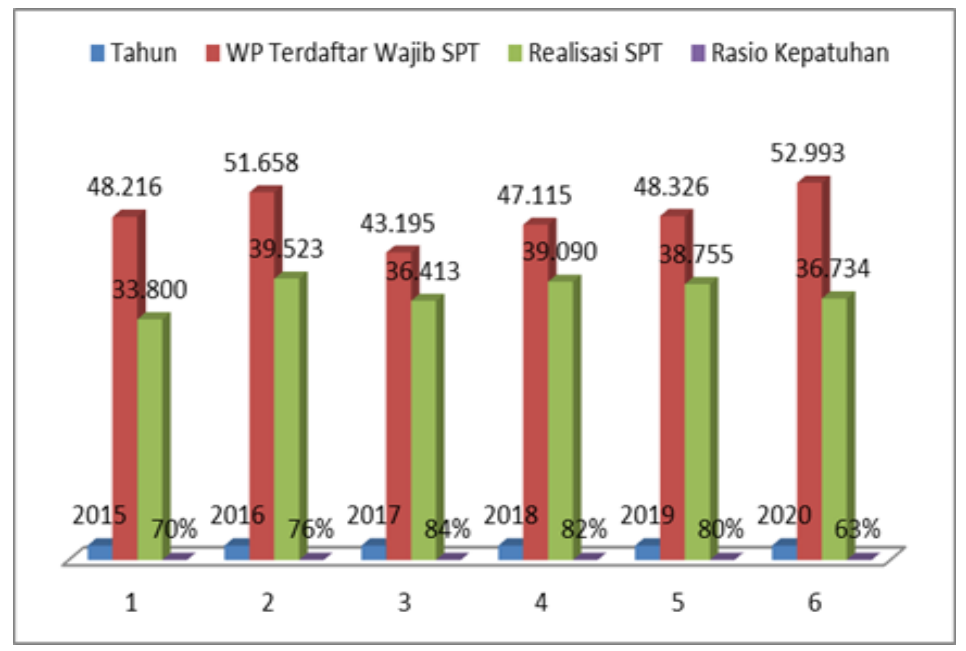

Source : KPP Pratama Surabaya Mulyorejo

Table 1.2 shows that the degree of compliance of individual taxpayers (OP) at KPP Pratama Surabaya Mulyorejo fluctuates. In 2015-2017 the degree of compliance of individual taxpayers as a whole, both employees and non-employees, always increased significantly by $7 \%$ in succession for 3 (three) years, namely $70 \%$ in $2015,77 \%$ in 2016 and $84 \%$ in 2017 subsequently decreased in 2018-2020 annually 3\% in 2018-2019 and 10\% in 2020 for total individual taxpayers who are not employees or employees. 2017 was the highest increase in taxpayer compliance since the last three years where the increase was $50 \%$ from $112 \%-162 \%$ and employees by $1 \%$ from $70 \%-71 \%$. The percentage of individual taxpayer compliance both as a whole and non-employees and employees in 2018-2020 has decreased in the implementation of taxpayer compliance so that an evaluation must be carried out both in terms of policies and services, with an average increase of $70 \%$ to $100 \%$ being a challenge and an opportunity for the Director General of Taxes, especially KPP Pratama Surabaya Mulyorejo, to increase taxpayer compliance.

The Director General of Taxes seeks to improve taxpayer compliance and achieve tax revenue targets, namely through tax audits and investigations as stipulated in 
EAJ (Economics and Accounting Journal) - Vol. 4, No. 1, Jan 2021 - Yanto, et al.

Permenkeu No. 17 / PMK / .03 / 2013 regarding Tax Audit. The purpose of the tax audit is to test compliance to fulfill its obligations related to taxation in an effort to provide legal certainty, justice, and guidance to taxpayers. The examination is carried out as a form of monitoring and guidance carried out by the Director General of Taxes so that the collection of taxes is carried out in accordance with the rules of the applicable tax law. Taxpayers who are subject to tax audits will affect the compliance of their taxpayers, the more inspections of taxpayers, the level of taxpayer compliance will increase (Dewi: 2017).

The results of the research conducted (Dwi: 2018) and (Putri:2020) state that the aspects that affect the level of taxpayer compliance, one of which is the knowledge of the taxpayer. Knowledge and understanding of taxes is the main key in building taxpayer compliance. Taxpayers are willing to pay taxes because they understand that delaying tax payments and reducing tax burdens have an impact on the lack of financial resources that can result in impeded state development (Rendy :2019).

Research results from (Nur: 2020) and (Yanto: 2020) fiscal services also play a role in influencing taxpayer compliance, fiscal services implemented by the fiscal services are expected to make it easier for taxpayers to obtain the necessary information, good service will increase public confidence, service fiscal services play a special role in increasing taxpayer compliance.

Risk preference is a moderating variable, because according to (Nur: 2020), in increasing taxpayer compliance it can also be from the influence of taxpayer choices on the various risks experienced by each taxpayer. Various risks that exist in taxpayers related to increasing taxpayer compliance include financial, health, social, occupational and safety risks. Based on the events that took place, there were taxpayers who tended to face the risks that occurred and some were actually avoiding them. This can affect the individual taxpayers in increasing compliance with their obligations. The researcher is interested in adding the risk preference variable as a moderating variable because it refers to the prospect theory being able to moderate the effect of the tax audit on taxpayer compliance. Research carried out (Yuslina: 2018) states that knowledge of tax moderation of risk preferences can increase mandatory compliance. His research (Safitri: 2018) shows that risk preference is able to moderate the impact of fiscal services on taxpayer compliance levels

Referring to the background of the problem related to taxpayer compliance, it will be carried out with the title "Taxpayer Compliance At KPP Pratama Surabaya Mulyorejo 
EAJ (Economics and Accounting Journal) - Vol. 4, No. 1, Jan 2021 - Yanto, et al.

With Risk Preference As A Moderated Variables".

\section{LITERATURE REVIEW AND HYPOTHESIS DEVELOPMENT}

\section{Prospect Theory}

It is a theory that describes how an individual will make a decision in an uncertain situation. The substance is a mechanism in determining an individual decision as opposed to the formation of values commonly experienced in economic science (Kahneman \& Tversky: 1979).

\section{Taxpayer Compliance}

Taxpayer compliance based on the opinion of Safri Nurmantu quoted by Siti Kunia Rahayu (2010: 138), reveals if:

"Compliance related to taxes can be interpreted as a condition in which taxpayers obey all tax obligations and exercise tax rights".

The definition of taxpayer compliance is based on the opinion of Chaizi Nasuchayang in Kurnia Rahayu (2010: 139), which states that taxpayer compliance can be explained:
a. Taxpayer's obligation to register.
b. Obey to submit the notification letter again.
c. Obey regarding the calculation and payment of payable taxes.
d. Obey regarding paying arrears.

\section{Tax Audit}

The definition of examination is based on Article 1 paragraph (25) of Law no. 28 of 2007 regarding the third amendment to Law no. 6 of 1983 regarding General Rules and Tax Procedures in Harahap (2013), namely: "Examination is a series of activities to collect and process data, information, and / or evidence which is carried out objectively and professionally based on inspection guidelines to measure compliance in fulfilling tax obligations and / or for other purposes to enforce the tax laws"

\section{Tax Knowledge}

Based on the definition of tax knowledge (Veronica Caroline: 2009: 7), namely: "tax knowledge is information that can be used by taxpayers as a guide in acting, deciding, and determining a direction or method related to the implementation of rights and obligations in the field of taxation." Thus, knowledge of taxation is taxrelated information obtained based on observations of individual intellect

\section{Fiscal Services}

Service is the process of providing service (providing assistance, taking care of, or preparing all the needs an individual needs). In addition, the fiscal services are tax officials. Then the tax services can mean the steps of the tax officer in providing assistance, taking care of 
EAJ (Economics and Accounting Journal) - Vol. 4, No. 1, Jan 2021 - Yanto, et al.

or preparing all the needs needed by the individual, namely the taxpayer (Yuslina: 2018)

\section{Risk Preferences}

Risk preference is a characteristic of an individual that can influence behavior (Sitkin \& Pablo: 1992). In concept, risk preference includes three areas, namely avoidance of risk. Neutral when handling risks and happy with risks. This theory explains that when taxpayers have a large level of risk it can affect their taxpayer compliance. So that when tax compliance is closely related to risk preferences, the level of taxpayer compliance is small, which means that taxpayers have a variety of high risks that can weaken their taxpayer compliance.

\section{Conceptual Framework and Research Hypothesis}

Based on the literature review above, a conceptual framework and hypothesis can be formulated:

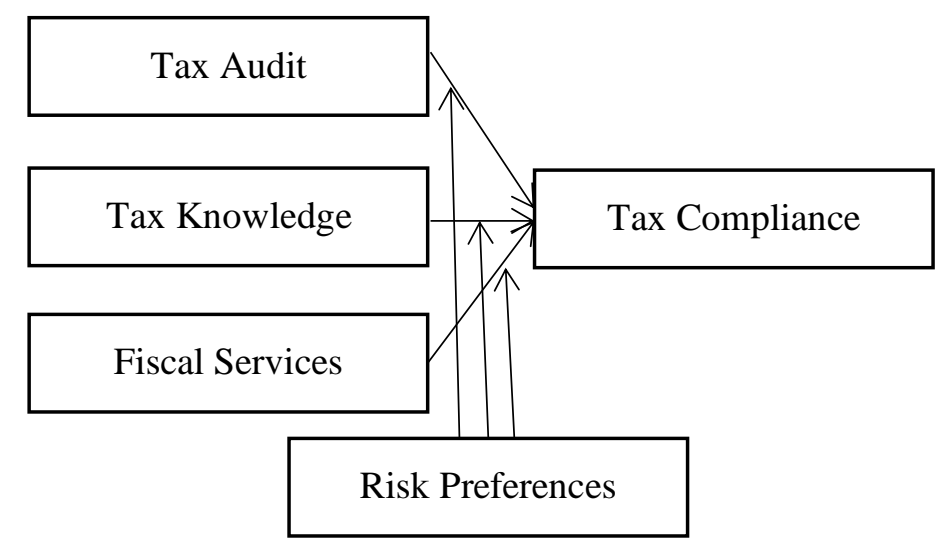

Figure 1. The conceptual framework

a. H1: There is a Tax Audit Effect on taxpayer compliance.

b. H2: There is an Influence of Taxation Knowledge on taxpayer compliance.

c. H3: There is an Influence of Fiscal Service on taxpayer compliance.

d. H4: There is an effect of tax audit on taxpayer compliance moderated by risk preference. e. H5: There is an Influence of Taxation Knowledge on taxpayer compliance moderated by Risk Preference.

f. H6: There is an Effect of Fiscal Service on taxpayer compliance moderated by Risk Preference. 
EAJ (Economics and Accounting Journal) - Vol. 4, No. 1, Jan 2021 - Yanto, et al.

\section{RESEARCH METHOD}

\section{Data Collection Techniques}

In collecting the data techniques, using a questionnaire in the form of a questionnaire, which is a list of questions given to individual taxpayer respondents at KPP Pratama Surabaya Mulyorejo. The questionnaire is a closed questionnaire, that is, the respondent is required to choose the answer that has been prepared from the questions given.

\section{Operational Definitions of Variables}

It is a definition of a variable by means of defining or specifying activities, as well as providing an operation needed to test related variables (Nazir, 2011: 126). The variable is measured by an ordinal scale and the measurement technique uses a Likert scale of 1-5.

\section{Sample Collection Techniques}

Population based (Sugiyono: 2017) is a generalization area which includes objects. The population, namely all individual taxpayers registered at KPP Pratama Surabaya Mulyorejo, totaling 52,993 taxpayers.

The opinion of the sample (Sugiyono: 2017) is that it is part of the sum and the unique attributes of the population concerned. The number of samples used is based on the Slovin formula, the smallest sample size is 99.814 and has rounded to 100 samples (Umar: 2010).

\section{Data Analysis Techniques}

Using GeSCA or structural equation models based on components. GeSCA was popularized by Heungsun Hwang, Hec Montreal and Yhoshio Takane in 2004 (Ghozali: 2008). Which aims to replace the factors with a linear combination of the indicators in the SEM analysis. The analytical model applied is the least squares method in estimating its parameters. This research uses the GeSCA program which is accessed online from http://www.sem-gesca.com/.

\section{RESULTS AND DISCUSSION}

\section{Results}

It is useful to determine whether exogenous variables have an effect on the endogenous. The qualification of the test is if the path coefficient is positive and CR (Critical Ratio) $\geq$ 1.96 , it means that there is a significant positive effect of exogenous variables on the endogenous variables. The results of the hypothesis test can be seen in the table below (Latan: 2014).

Table 4.1 Path Coefficient Value 
EAJ (Economics and Accounting Journal) - Vol. 4, No. 1, Jan 2021 - Yanto, et al.

\begin{tabular}{|c|c|c|c|c|} 
Tax Audit & Taxpayer Compliance & -10.024 & 3.227 & $3.11^{*}$ \\
\hline Tax Knowledge & Taxpayer Compliance & 6.520 & 3.780 & 1,73 \\
\hline Fiscal Services & Taxpayer Compliance & 6.909 & 1.339 & $5.16^{*}$ \\
\hline Tax Audit * Risk Preferences & Taxpayer Compliance & 16.322 & 5.635 & $2.90^{*}$ \\
\hline Tax Knowledge * Risk Preferences & Taxpayer Compliance & -9.080 & 5.324 & 1,71 \\
\hline Fiscal Services * Risk Preferences & Taxpayer Compliance & -11.692 & 2.095 & $5.58^{*}$ \\
\hline
\end{tabular}

Source : Output Path Coefficient of Generalized Structured Component Analysis (GSCA)

Description: * (Significant)

X1: Tax Audit

X2: Tax Knowledge

X3: Fiscal Ministry

Z1: Risk Preference

Y1: Taxpayer Compliance

Based on the table above, it can be seen that the measurement model formed is:

Equation 1: $\mathrm{Y}=-10,024 \mathrm{X} 1+$ $6,520 \mathrm{X} 2+6,909 \mathrm{X} 3+2,877 \mathrm{Z} 1+$ $16,322 \mathrm{X} 1 * \mathrm{Z} 1-9,080 \mathrm{X} 2 * \mathrm{Z} 1-$ $11,692 \mathrm{X} 3 * \mathrm{Z} 1$

\section{Discussion}

The Effect of Tax Audit on .Taxpayer Compliance

Produces a path coefficient of $-10,024$ with a CR (critical ratio) value of 3.11. The test results show that the path coefficient is negative and CR (critical ratio)> 1.96. this means that the tax audit has a significant negative effect on taxpayer compliance. The results show that if the tax audit improves, it tends to increase taxpayer compliance.

The results of this research are the same as those carried out by (Dewi: 2017) who concluded that the tax audit affects taxpayer compliance.

\section{The Effect of Tax Knowledge on Taxpayer Compliance}

Produces a path coefficient of 6,520 with a CR (critical ratio) value of 1.73 . The test results show that the path coefficient is positive and CR (critical ratio) <1.96. This means that knowledge of taxation has an insignificant positive effect on taxpayer compliance. The results show that if the more tax knowledge the taxpayer has, it tends to increase taxpayer compliance, but the increase is not significant.

The results of this research are the same as those carried out (Dwi: 2018) which concludes that knowledge of taxation affects taxpayer compliance.

\section{The Effect of Fiscal Services on Taxpayer Compliance}

Produces a path coefficient of 6,909 with a CR (critical ratio) value of 5.16. The test results show that the path coefficient is positive and CR (critical ratio) $>1.96$. This means that fiscal services have a significant positive effect on taxpayer compliance. The results show that if 
EAJ (Economics and Accounting Journal) - Vol. 4, No. 1, Jan 2021 - Yanto, et al.

the fiscal services are better, it tends to increase taxpayer compliance.

The results of this research are the same as those carried out (Nur: 2020) and (Yanto: 2020) which show that taxpayer services affect the level of taxpayer compliance

The Effect of Tax Audit is Moderated by Risk Preference on Taxpayer Compliance

Produces a path coefficient of 16,322 with a CR (critical ratio) value of 2.90. This shows that CR (critical ratio) $>1.96$. It means that risk preference moderates the effect of tax audit on taxpayer compliance. The test results show that the coefficient of the effect of tax audit interaction with risk preference moderation on taxpayer compliance is significant.

The results of his research are the same as the prospect theory popularized by (Kahneman \& Tversky: 1979) showing that tax audits that are moderated by risk preferences affect the level of taxpayer compliance.

The Effect of Tax Knowledge is Moderated by Risk Preference on Taxpayer Compliance

Produces a path coefficient of -9.080 with a CR (critical ratio) value of 1.71. This shows that CR (critical ratio) <1.96. Therefore, it can be interpreted if risk preference does not moderate the effect of tax knowledge on taxpayer compliance. The test results show that the coefficient of the influence of the interaction of tax knowledge with moderation of risk preference on taxpayer compliance is not significant.

The results of this research are the same as those carried out (Yuslina: 2020) which shows that taxation knowledge moderated by risk preferences affects the level of taxpayer compliance.

\section{The Effect of Fiscal Services is Moderated by Risk Preference on Taxpayer Compliance}

Produces a path coefficient of -11,692 with a CR (critical ratio) value of 5.58. This shows if $\mathrm{CR}$ (critical ratio)> 1.96. This means if risk preferences moderate the effect of fiscal services on taxpayer compliance. The test results show that the coefficient of the influence of taxpayer service interaction with risk preference moderation on taxpayer compliance is significant.

The results of this research are the same as those carried out (Safitri: 2020) which shows that fiscal services services which are moderated by risk preferences have an influence on the level of taxpayer compliance.

\section{CONCLUSION}

Based on the results of the discussion regarding "Taxpayer Compliance at KPP Pratama Surabaya Mulyorejo with Risk Preference as Moderation Variable" it can be concluded as follows: 
EAJ (Economics and Accounting Journal) - Vol. 4, No. 1, Jan 2021 - Yanto, et al.

a. Tax Audit has a significant effect on taxpayer compliance.

b. Tax knowledge does not have a significant effect on taxpayer compliance.

c. Fiscal services have a significant effect on taxpayer compliance.

d. Risk preference is able to moderate the effect of tax audit on taxpayer compliance.

e. Risk preference can moderate the effect of tax knowledge on taxpayer compliance.

Risk preference is able to moderate the influence of fiscal services on taxpayer compliance.

\section{REFERENCES}

Caroline, Veronica. (2009). Pengetahuan Pajak. Jakarta: Salemba Empat.

Dewi, A. K., Darmansyah., \& Djadang, S. (2017). Antecedent terhadap Kepatuhan Wajib Pajak Badan Dengan Tax Amnesty Sebagai Pemoderasi. JIAFE (Jurnal Ilmiah Akuntansi Fakultas Ekonomi) Volume 3 No. 1 Tahun 2017, Hal. 49-61.E-ISSN 2502-4159.

Direktorat Jenderal Pajak. UndangUndang Nomor 28 Tahun (2007). Undang-undang Nomor 6 tahun 1983 tentang Ketentuan Umum dan tata Cara Perpajakan.
Direktorat Jenderal Pajak. Masalah Kepatuhan Wajib Pajak Di Indonesia Tahun (2015-2019).

Direktorat Jenderal Pajak. Rasio Pajak Di Indonesia Tahun (2015-2019).

Dwi, Paramita, Pranandita.(2018). Pengaruh Pemahaman Peraturan Perpajakan dan Kesadaran Wajib Pajak Terhadap Kepatuhan Wajib Pajak Dengan Preferensi Risiko Sebagai Variabel Moderating. Journal of Accounting 2018. Fakultas Ekonomi Universitas Pandanaran Semarang.

Husein, Umar. (2010). Metode Penelitian Untuk Skripsi dan Tesis Bisnis Edisi 11. Jakarta: PT Raja Grafindo Persada.

Hwang, Heungsun dan Yoshio Takane. (2004). "Generalized Structured Component Analysis." Psychometrika, 69 (1), 81-99.

Kahneman, Daniel dan Amos Tversky. (1979). Prospect Theory: An Analysis of Decision Under Risk. Econometrica, vol. 47, pp.263291.

Latan, Hengky. (2014). Teori, Konsep dan Aplikasi Menggunakan Program Generalized Structured Component Analysis (GeSCA). Bandung: Sarana Tutorial Nurani Sejahtera. 
EAJ (Economics and Accounting Journal) - Vol. 4, No. 1, Jan 2021 - Yanto, et al.

Nazir.Mohammad,Ph.D.(2011).

Metode Penelitian. Jakarta:

Ghalia Indonesia.

Nur, Mulyani, (2020). Pengaruh Sikap Rasional, Pelayanan, Dan Pemahaman Peraturan Pajak Terhadap Tingkat Kepatuhan Wajib Pajak Dengan Preferensi Risiko Sebagai Variabel Moderating. Prosiding Seminar Nasional, ISSN (P): 2615 2584.

Peraturan Menteri Keuangan Republik Indonesia Nomor 17/PMK.03/2013 Tentang Tata Cara Pemeriksaan.

Putri, Devi, \& Amijaya. (2020). Knowlwedge of Taxation and Fiscus Service on Taxpayers Compliance.

Dinasti International Journal of Economics, Finance and Accounting. Volume 1, Issue 1, March 2020.

Rendy, R., \& Irawati, W. (2019). Understanding Of Tax Rules, Tax Tariffs and Tax-Rights Consciousness on E-Commerce Users Tax Compliance. EAJ (Economics And Accounting Journal), 2(2), 141-148.

Siti Kurnia Rahayu. (2010). Perpajakan Indonesia: Konsep Dan Aspek Formal. Jakarta: Graha Ilmu.

Sitkin, S.B., \& Pablo, A.L. (1992). Reconceptualizing the determinants of risk behaviour.
Academy of Management Review;17, pp. 9-38.

Sugiyono. (2017). Metode Penelitian

Kuantitatif, Kualitatif, dan $R \& D$. Bandung: Alfabeta.

Yanto, Iksan, Hastut. (2020). Pengaruh Tax Amnesty, Pengetahuan Perpajakan dan Pelayanan Fiskus Terhadap Kepatuhan Wajib Pajak. Proceedings of Economic Business and Governance Challenges 2019, October 03, Indonesia, 2020 EAI DOI 10.4108/eai.3-102019.2291943.

Yuslina, Tanjung, dan Silfi .(2018).’Pengaruh Pelayanan Fiskus, Pengetahuan Perpajakan dan Kesadaran Wajib Pajak Terhadap Kepatuhan Wajib Pajak dengan Kondisi Keuangan dan Preferensi Resiko Wajib Pajak Sebagai Variabel Moderating (Study Empiris pada Wajib Pajak Orang Pribadi di Kota Pekanbaru)". Jurnal Akuntansi \& Manajemen, Vol 13, No. 2 2018, 40-57 